\title{
THE CONSTITUTIONALITY OF THE TENNESSEE ANTI-EVOLUTION ACT
}

\author{
WIILIAM WALLER
}

The Tennessee General Assembly of 1925 enacted the most widely discussed statute of recent years, popularly lnown as the Tennessee Anti-Evolution Act:

"AN ACT prohibiting the teaching of the Evolution Theory in all the Universities, Normals and all other public sehools of Tennesee, which are supported in whole or in part by the public sehool funds of the State, and to provide penalties for the violations thereof.

SECTION 1. Be it enacted by the Gencral Asscmbly of the State of Tennessee, That it shall be unlawful for any teacher in any of the Universities, Normals and all other public schools of the State which are supported in whole or in part by the publie school funds of the State, to teach any theory that denies the story of the Divine Creation of man as taught in the Bible, and to teach instead that man has descended from a lower order of animals.

SECTION 2. Be it further enacted, That any teacher found guilty of the violation of this Act, shall be guilty of a misdemeanor and upon conviction, shall be fined not less than One Hundred $(\$ 100.00)$ Dollars nor more than Five Hundred $(\$ 500.00)$ Dollars for each offense.

SECTION 3. Be it further enacted, That this Act take effect from and after its passage, the public welfare requiring it."

Much wonder has been expressed both in this country and in Europe as to the factors which made such legislation possible. These factors were three in number: (1) an aggressive campaign by a militant minority of religious zealots of the "Fundamentalise" faith; (2) lack of knowledge of modern scientific and religious thought in the rural districts which control Tennessee politically; (3) political cowardice and demagogy.

The majority of the members of the legislature, including those who voted for the bill, were sorry that the issue was raised. Once raised, however, their training and background were such that many of them honestly believed that a vote against the bill was a vote against religion. Most of the affirmative votes were conscientiously cast. Other members who would have voted against the bill had they voted conscientiously, were afraid that by so doing they would lose the support of many of their fellow legislators for other measures which they were sponsoring, and would incur disfavor with the voters back home. They therefore yielded to political expediency.

With the death of the great Fundamentalist leader, William 
Jennings Bryan, and the immense unfavorable publicity which the Tennessee statute has received, the probability is that similar laws will not be passed in other states. The Georgia legislature, representing an electorate of much the same rural complexion as Tennessee, last summer defeated such a measure by an overwhelming vote.

The lawyer is interested in such legislation as the Tennessee Anti-Evolution Act especially from the standpoint of its constitutionality, and it is proposed to discuss this question.

The state has two bases of control over schools, which we may denominate as "governmental" or "police power" control and "proprietary" control. The first, applicable to all schools, public and private, is expressed in the following paragraph of the opinion of Mr. Justice MreReynolds in the Oregon School Law case, ${ }^{1}$ stating what was not there involved:

"No question is raised concerning the power of the state reasonably to regulate all schools, to inspect, supervise and examine them, their teachers and pupils; to require that all children of proper age attend some school, that teachers shall be of good moral character and patriotic disposition, that certain studies plainly essential to good citizenship must be taught, and that nothing be taught which is manifestly inimical to the public welfare."

Very much broader is the state's proprietary control over public institutions, including the power to prescribe a curriculum, ${ }^{2}$ to select textbooks, ${ }^{3}$ to impose disciplinary regulations for students, ${ }^{4}$ and to exercise many other prerogatives of an owner and employer.

In Meyer v. Nebraska, ${ }^{5}$ the Supreme Court held invalid a state statute punishing a teacher in any school who should teach a foreign language to pupils who had not reached the eighth grade, the ground of the decision being that the Fourteenth Amendment was violated. As stated by Mr. Justice McReynolds, who delivered the opinion: "His right thus to teach and the right of parents to engage him so to instruct their children, we think; are within the liberty of the Amendment."

If the Tennessee statute were not confined to public institutions this decision would doubtless be controlling. In the present day an enlightened and conscientious court would not hold that the teaching of evolution is "manifestly inimical" to the public welfare. As "police power" legislation it would be clearly invalid. But a more difficult question is whether the statute may not be sustained as an exercise of the state's proprietary control over public educational institutions.

\footnotetext{
${ }^{1}$ Pierce v. Society of Sisters of Holy Names (1925) 267 U. S. -, 45 Sup. Ct. 571, 573.

2 See Meyer v. Nebraska (1923) 262 U. S. 390, 400, 43 Sup. Ct. 625, 628.

3 Leeper v. State (1899) 103 Tenn. 500, 53 S. W. 962.

4 Waugh v. Mississippi University (1915) 237 U. S. 589, 35 Sup. Ct. 720.

- Supra note 2.
} 
The statute could hardly be said to "prescribe a curriculum". It does not abolish the teaching of certain scientific subjects and thus save that expense to the state. On the other hand it assumes that they are still to be taught. No change whatever is made in any curriculum of any school. What the statute undertakes to do is to set aside a scientific doctrine which would naturally be taught as an integral and vital part of these subjects, and to substitute a standard of truth of its own. The public schools, state normal schools and state university are thus deprived of their character of purely educational institutions, and are given the rôle of protectors of a partisan belief or dogma.

The proponents of the statute look upon the state, however, as having equally as broad control over public institutions of learning as the owner of a private school has over his establishment. They urge the constitutionality of the Act upon the broad ground that the taxpayers, through the legislature, may say what sort of instruction their money shall provide, or to put it another way, that the state, as the employer of the teacher, may direct his work as it sees fit. If this view is correct-if no rule of reason is to be applied-a protectionist majority in a legislative body may say that the teacher of economics shall not expound the free trade doctrine; a Roman Catholic majority may say that the teacher of history shall teach nothing reflecting discredit upon any of the Popes; or an especially mediaeval-minded legislature may provide that the teacher of geography shall teach nothing to conflict with the Biblical cosmogony of a flat, four-cornered, stationary earth and a sun and moon which move around it in a canopy-like "firmament. Does our form of government permit such a "tyranny of the majority" in matters affecting public education, or have the minority rights which are constitutionally protected?

It is unquestionably true that a state government in its capacity of paymaster has a degree of control over public employees and institutions which it does not possess over private persons. But to the doctrine that the majority, through the state government, may control the disposition of public funds there is the well established exception that these funds shall not be diverted to other than "public purposes"." Such a diversion would constitute a taking of the property of the minority or dissenting taxpayers without "due process of law". And, necessarily, the majority are not the sole judges of what is a public purpose. In the courts must rest the ultimate decision. Here, in the final analysis, must be sought the solution of the present problem of the extent of a state legislature's control over public education. While it is unthinkable that "academic freedom" should be permitted beyond proper bounds (whatever they may be), it is equally unthinliable

6 Ferrell v. Doak (1925) 152 Tenn. -, 275 S. W. 29; Loan Ascociation v Topelia (1875, U. S.) 20 Wall. 655. 
that a state legislature should be permitted to dictate arbitrarily upon matters which, after all, are best determined by specialists in their peculiar field. The minority taxpayer, who contributes to public education, may insist that the courts impose checks and balances upon the legislature, just as the legislature, directly or through subordinate boards and agencies, may and should impose reasonable checks and balances upon the teacher. Abuse of discretion upon either side should not be countenanced.

Most of the cases discussing the proprietary control by a state government and its agencies over public institutions and works, and the limitations upon that control, involve regulations imposed upon contractors for public improvements in regard to their laborers. The great weight of authority, including decisions of the Supreme Court of the United States, is that the state in its proprietary capacity may lawfully require such contractors not to work their laborers over eight hours a day, ${ }^{7}$ and to employ only resident laborers. ${ }^{8}$ Neither a contractor nor a laborer may complain of such a requirement. They need not work for the state, and if they accept employment they must accept whatever conditions are imposed. Neither may a taxpayer complain of the increased cost of the improvement. There is a reasonable argument to be made that regulations limiting the hours of labor and excluding aliens from public employment are in furtherance of a valid public policy-and with disputable questions of public policy the courts have no concern. On the other hand, regulations that only union labor shall be employed have uniformly been held invalid as resulting in a taking of the taxpayers' property for a "non-public purpose". It is immaterial that the authors of such measures honestly believed that they were for the public good. The courts must make the final decision and must measure proprietary legislation, as they measure other legislation, by a rule of reason. ${ }^{10}$

${ }^{7}$ Atkin v. Kansas (1903) 191 U. S. 207, 24 Sup. Ct. 24 . See notes in 1 Ann. Cas. 46, and 8 L. R. A. (N. S.) 131. The Federal government may impose the same regulations as to Federal improvements. Ellis v. Unitod States (1907) 206 U. S. 246, 27 Sup. Ct. 600.

8 Heim v. McCall (1915) 239 U. S. 175, 36 Sup. Ct. 78. See Ann. Cas. 1915B 1271, note.

9 See 23 L. R. A. (N. S.) 815, note.

10 There is, of course, one school of thought in the country, represented upon the Supreme Court by Justices Holmes and Brandeis, which denies the propriety of judicial interference, especially by the Federal Courts, with any state legislation as denying "due process of law," except where there is a procedural vice. If the state legislature make the bed, let the people lie in it, and if the law is bad it will eventually be repealed. So runs the argument, and much may be said in its favor. But the doctrine has been settled the other way. Recognizing and accepting the mediocrity and sometimes venality of our legislative bodies and their tendency to pass, at times, arbitrary and capricious laws, we have evolved the judicial veto, placed in the hands of men who are presumably of a higher order of intelli- 
These same principles are applicable to educational institutions. Education is unquestionably a public purpose for which taxation is lawful. The question to be determined, however, is whether the same thing may be said of deliberately partisan instructionwhether "education" is a public purpose when it is directed not by the trend of scientific and scholastic development, and by the consensus of opinion of specialists in education who have chosen teaching as their profession, but by the beliefs of a majority of the members of a legislative body.

If the legislature may expend public moneys in providing public instruction in geology and biology according to a theological ereed rather than according to modern science, then it may establish a state theological seminary for the promulgation of that creed. It is immaterial that the Tennessee statute is negative in form and provides merely that a certain scientific doctrine shall not be taught instead of a certain theological dogma, without providing affirmatively that the latter shall be taught. Propaganda of any kind requires defense as well as offense-a shield as well as a sword-and when the weakness of a dogma is its conflict with a scientific theory, the suppression of that fact or theory in public institutions of learning is equivalent to the use of public moneys for the propagation of the dogma.

Is such a direction of teaching by the legislature a reasonable exercise of its proprietary control over public schools and institutions, involving merely a disputable question of public policy, or is it so palpably arbitrary as to result in taxation for an unlawful purpose? In considering this question let us inquire into the public policy of the state of Tennessee as expressed in its constitution.

Article 1, section 3 of the Constitution of 1870 provides :

"That all men have a natural and indefeasible right to worship Almighty God according to the dictates of their own conscience; that no man can of right, be compelled to attend, erect, or support any place of worship, or to maintain any minister against his consent; that no human authority can, in any case whatever, control or interfere with the rights of conscience; and that no preference

gence and political honesty. And so, while the cases contain many declarations that a judge may not substitute his own ideas of public policy for the judgment of the lawmaker, it is nevertheless apparent that the courts regard the field of public policy as limited by what is, in the opinion of the judge, reasonable. If the legislature reasonably differs from the court, the statute is valid; if the legislature unreasonably and arbitrarily differs, the statute is invalid. If a standard of reasonableness is to be employed by the courts where the legislation takes one form, it must for consistency's sake be employed where it takes another. If arbitrary "police power" laws are invalid, how may the courts consistently evade the duty to declare arbitrary tasation and arbitrary proprietary legislation likewise invalid-although, to be sure, the domain of reasonableness may be broader as respects one form of legislation than as respects the other? 
shall ever be given, by law, to any religious establishment or mode of worship."

Article 1, section 4 provides:

"That no political or religious test, other than an oath to support the constitution of the United States and of this state, shall ever be required as a qualification to any office or public trust under this state."

Article 11, section 12 provides:

"Knowledge, learning and virtue, being essential to the preservation of republican institutions, and the diffusion of the opportunities and advantages of education throughout the different portions of the state, being highly conducive to the promotion of this end, it shall be the duty of the general assembly in all future periods of this government, to cherish literature and science. And the fund called the common school fund, and all the lands and proceeds thereof, dividends, stocks, and other property of every description whatever, heretofore by law appropriated by the general assembly of this state for the use of common schools, and all such as shall hereafter be appropriated, shall remain a perpetual fund, the principal of which shall never be diminished by legislative appropriations; and the interest thereof shall be inviolably appropriated to the support and encouragement of common schools throughout the state, and for the equal benefit of all the people thereof; and no law shall be made authorizing said fund or any part thereof to be diverted to any other use than the support and encouragement of common schools. The state taxes, derived hereafter from polls shall be appropriated to educational purposes, in such manner as the general assembly shall from time to time direct by law."

Bearing in mind that the evolution of man is a scientific doctrine, and the Special Creation of man a theological doctrine, is it not significant that the legislature is expressly directed to cherish science, but that religion and theology are to be left entirely free from governmental interference or aid? Is it not a fair conclusion that where science and theology conflict, the legislature may not give a preference to the latter by the use of moneys devoted by the Constitution to educational purposes?

A number of state constitutions, especially in states where there are strong religious minorities-a condition which tends to inject religion into politics-contain express provisions that public aid shall not be given in support of sectarian instruction or institutions. ${ }^{1 x}$ In Tennessee and other states the constitution framers evidently regarded the principle of separation of church and state as too fundamental and thoroughly accepted to call for a more detailed consideration than the broad and general provisions above quoted. The present division and antagonism in all sects between Fundamentalists and Modernists-so violent as to lead one division to seek legislative aid-could not well have been anticipated. Even in the absence of express constitutional provision, however,

11 See 5 A. L. R. 866, 883, note. 
it seems clear that public moneys cannot be appropriated to the aid of a sectarian school or to provide sectarian instruction, since such an appropriation would seem not to be for a "public purpose".22

That the control of a state legislature over public institutions of learning is limited by what is reasonable and not arbitrary or capricious, is clearly implied in the opinion of the Supreme Court in Waugh $v$. Mississippi University ${ }^{13}$ holding valid as a rcasonable disciplinary regulation a Mississippi statute prohibiting Greek letter fraternities and other societies in the educational institutions of the state. Speaking through Mr. Justice MrKenna, the Court said:

"It is to be remembered that the University was established by the State and is under the control of the State, and the enactment of the statute may have been induced by the opinion that membership in the prohibited societies divided the attention of the students and distracted from that singleness of purpose which the State desired to exist in its public educational institutions. It is not for us to entertain conjectures in opposition to the views of the State and annul its regulations upon disputable considerations of their wisdom or necessity."

It was further held that an exception, of "students already" entered" was not arbitrary but was "based on an obvious and rational distinction"-viz., "an obvious principal of construction, and sometimes of justice, that laws are not to be construed retrospectively."

Within broad limits the legislature is undoubtedly the arbiter of what is the public policy of the state, and of what is a "public purpose"; and the courts may not properly interfere and substitute their own judgment. But when those limits are transgressed, and a capricious legislature enacts a law by which public moneys are expended for a purpose which clearly contravenes those conceptions of public policy which are expressed in the State Constitution, and especially such a fundamental principle as the separation of church and state, are we to say that the hands of the judiciary are still tied, and that the minority have no protection? It seems clear that a law which arbitrarily prescribes that in public institutions of learning an important and well established scientific doctrine shall be displaced in favor of a theological dogma is unconstitutional and void upon the broad ground that it results in taxation for a private purpose.

If this view is correct, the statute is invalid under the "due process of law" clauses of both the State Constitution and the Fourteenth Amendment of the Federal Constitution. It is true that the Federal Supreme Court has gone far in accepting the judgment of state courts as to the public purpose of state legisla-

12 Atchison, T. \& S. F. R. R. v. City of Atchison (1892) 47 Fan. 712, 28 Pac. 1000; 1 Cooley, Taxation (4th ed. 1924) sec. 201.

${ }^{13}$ Supia note 4, at 596 . See also 27 A. L. R. 1074, note. 
tive appropriations of money or exercises of the power of taxation, on the ground that what is a public purpose may vary with different local conditions with which the state courts are more familiar. ${ }^{14}$ But so far as the Anti-Evolution Act is concerned, it is difficult to conceive of any local Tennessee conditions which would not apply in the entire country.

It may well be contended also that the Anti-Evolution Act is invalid on the narrower ground that it conflicts with the provisions of the State Constitution, hereinbefore quoted, and especially with the clause that "no preference shall ever be given by law to any religious establishment or mode of worship". Proponents of the Act have suggested that if, under this clause, the Bible cannot be taught in the public schools, by the same token nothing can be taught which conflicts with the Bible, and that the statute is simply carrying the constitutional provision into effect. This view presupposes the untenable premise that evolution is a religious or theological doctrine. This is of course untrue, although it is evident that Biblical literalists have incorporated disbelief of evolution into their theology. But to prohibit the teaching of a scientific doctrine because it conflicts with a theological creed is of course, as already 'pointed out, to give a preference by law to that creed.

Narrowly construing the language of this constitutional provision it may be said that it prohibits a preference to a "religious establishment", not to a creed. But to uphold the statute upon such a ground would be to ignore what has been previously suggested, that such a question as this could not well have been anticipated by the framers of the Constitution, and hence that a solution of the problem must be sought in the broad and general principles which they announced. Furthermore, the Fundamentalists have already perfected interdenominational organizations or "establishments". Horizontal and sectarian lines are fading away in comparison with the vertical cleavage in all sects between the adherents of a literal interpretation of the Bible-who regard the Genesis accounts of the Special Creation of man as an essential part of their religion-and those on the other hand who regard the Bible as a book of religion and literature and not of history or science, and therefore view these accounts as poetry or allegory. The statute converts the public schools, state normals and state university into protectors of the former division - into citadels of a theological creed or dogma of a particular "religious establishment"-and this in the very teeth of the constitutional mandate that the general assembly shall cherish science.

From the standpoint of the teacher, as well as that of the taxpayer, the constitutionality of the statute is open to serious question. The "rights of conscience" of the teacher who believes

14 Green v. Frazier (1920) 253 U. S. 233, 40 Sup. Ct. 499. 
in evolution are controlled through the requirement that in teaching science he shall suppress one of its most important principles. If it were possible as a practical matter to escape this difficulty by filling the chairs of geology and biology in public institutions of learning with scientists who literally believe the stories of Adam and Eve and Noah's ark, the result would in effect be the imposition of a new "test" for persons holding a "public trust". 29

Can the teacher complain upon Federal constitutional grounds? In Meyer v. Nebraska, ${ }^{10}$ a teacher was indicted for teaching German, contrary to a statute. The Supreme Court held that the statute was arbitrary, infringed the teacher's liberty, and violated the Fourteenth Amendment. The Tennessee statute is different in that only public institutions are affected. The difficulty suggests itself, however, that the state, while invoking its proprietary authority as an employer and paymaster, has drawn upon its governmental power ("police power") of defining and punishing crimes. The two elements are distinct. Thus, a legislature may delegate to a school board the proprietary functions of prescribing a curriculum and making other proper regulations for public schools; but it may not delegate the power to prescribe the punishment. ${ }^{27}$ Furthermore, there is no contractual element in the present statute; it became applicable upon passage to teachers already employed, as well as to those to be employed in the future. ${ }^{18}$ It would seem, therefore, that, being a criminal statute, it is not to be measured by the standards of proprietary legislation; and certainly it is void if measured by any other.

It is quite likely, however, that the courts in passing upon the constitutionality of the Tennessee Anti-Evolution Act will not reach any of the questions hitherto discussed, but that the Tennessee Supreme Court will declare it invalid as not complying with Article 2, section 17 of the State Constitution, providing that, "No bill shall become a law which embraces more than one subject, that subject to be expressed in the title." Far more

${ }^{25}$ Cf. State v. Bird (1913) 253 Mo. 569,162 S. W. 119, holding that the position of guardian of a minor is a "public trust."

${ }^{16}$ Supra note 2.

37 Cf. State v. McNally (1896) 48 La. Ann. 1450, 21 So. 27.

18 The statute is thus distinguishable from those involved in Lecper $v$. State, supra note 3; Atlin v. Kansas, supra note 7; Ellis v. Unitcd States, supra note 7; Heim v. MicCall, supra note 8; and others. A person who has notice of the conditions of his employment when the contract is made may be precluded from complaining. By violating the conditions imposed upon him he becomes guilty of a breach of contract But a teacher who has been employed to teach science for a year and is directed in the middle of the year to teach nothing which conflicts with certain religious beliefs-though an important part of the course which he was employed to teach-is in a very different situation. In such a case the employer is the one who, by imposing the conditions, is guilty of the breach of contract. 
Tennessee statutes have been held unconstitutional under this than under any other constitutional provision..$^{10}$

The title or caption of the present statute indicates that it is an act to prohibit the "teaching of the evolution theory" in public educational institutions. The body of the Act, however, makes it unlawful "to teach any theory that denies the story of the Divine Creation of man as taught in the Bible and to teach instead that man has descended from a lower order of animals". If this language means anything at all, it means that the teaching of evolution is not unlawful unless it is taught instead of the Bible story. In other words, if the teacher, after explaining and expounding the evolution theory, also explains and expounds the Bible story and tells the students to take their choice, he has not violated the statute. To convict a teacher of a violation of the statute the prosecution must prove not merely that the defendant taught the evolution theory but that he taught it instead of the Bible story,- - that is to say, either that he ignored the latter entirely, or that he taught the former as fact and the latter as fiction. But of this essential element of the misdemeanor the title of the Act gives no indication. The title fails to give sufficient notice of the purpose, found in the body, to enact the Bible story of the origin of man into a standard of truth for scientific education.

It may be thought that this is an incorrect and unduly narrow construction of the statute. It is very obscurely worded and it is possible that its authors had in mind something different from its literal meaning. But a penal statute must be strictly construed. Certainly, if we discard this construction, the statute is void for uncertainty. A criminal statute must be definite in meaning, so that one may know what he may and may not legally do. 20

These questions, however, are of minor importance. The question in which lawyers and laymen alike are interested, and an answer to which by the courts they will anxiously await, is whether a state legislature has an unlimited control over what shall and shall not be taught in schools and institutions of learning supported by taxation, or whether the minority taxpayer may insist that such control be reasonably exercised, and exercised in the interests of education rather than theology.

19 Ragio v. State (1888) 86 Tenn. 272, 6 S. W. 401; State v. Bradt (1899) 103 Tenn. 584, 53 S. W. 942; State v. Hayes (1906) 116 Tenn. 40, 93 S. W. 98; State v. Cumberland Club (1916) 136 Tenn. 84, 188 S. W. 583.

${ }^{20}$ United States v. Cohen Grocery Co. (1921) 255 U. S. 81, 41 Sup. Ct. 298. Chicago \& N. W. Ry. v. Railroad and W. Commission (1922, D. C. D. Minn.) 280 Fed. 387; Wabash Ry. v. O'Bryan (1922, E. D. Mo.) 285 Fed. 583. 